\title{
From bench to bedside, work in cell-based myocardial regeneration therapy
}

\author{
Shigeru Miyagawa, Yoshiki Sawa
}

Department of Cardiovascular Surgery, Osaka University Graduate School of Medicine El, Osaka, Japan

Email: sawa-p@surg1.med.osaka-u.ac.jp

Received 31 October 2013; revised 4 December 2013; accepted 14 December 2013

Copyright (C) 2014 Shigeru Miyagawa, Yoshiki Sawa. This is an open access article distributed under the Creative Commons Attribution License, which permits unrestricted use, distribution, and reproduction in any medium, provided the original work is properly cited. In accordance of the Creative Commons Attribution License all Copyrights (C) 2014 are reserved for SCIRP and the owner of the intellectual property Shigeru Miyagawa, Yoshiki Sawa. All Copyright @ 2014 are guarded by law and by SCIRP as a guardian.

\section{ABSTRACT}

In clinical cellular cardiomyoplasty, bone marrow cells and myoblasts are introduced mainly to ischemic cardiomyopathy tissue via several cell delivery systems, such as needle injection or catheter. These clinical studies have demonstrated the safety and feasibility of this technique, but its effectiveness for treating heart failure, especially in the long term, is still under discussion. Neither of these cell types can differentiate into cardiomyocytes; rather, they improve the failing heart mainly by the paracrine effects of some cytokines, such as Hepatocyte growth factor (HGF) and Vascular endothelial growth factor (VEGF). Thus, many researchers have a great interest in stem cells, which exist in bone marrow, circulating blood, atrium, and adipose tissue, and can differentiate into cardiomyocytes. Although several stem cells with the potential to differentiate into various cell types have been reported, few can differentiate into cardiomyocytes. Moreover, beating cells that can demonstrate synchronized contraction with native cardiomyocytes are critical for the complete repair of severe heart failure. Therefore, stem cells with a high differentiation capacity should be explored for the goal of completely repairing severely damaged myocardium. In this review, we summarize the clinical protocols and basic experiments for cellular cardiomyoplasty using bone marrow cells, myoblasts, and other stem cells.

\section{KEYWORDS}

\section{Stem Cells; Heart Failure; Cell Therapy}

\section{INTRODUCTION}

To overcome heart failure many basical studies have been done and some technologies have been introduced to the treatment of heart failure clinically based on the experimental data.

Although cell therapy was recently introduced to clinical situation in heart failure, tremendous experimental studies (Bench work) have been done before clinical trials (Bed side work). In this review we present and analyze recent achievements in the laboratory and clinic in cellular cardiomyoplasty.

\section{CELLULAR CARDIOMYOPLASTY}

The adult heart has no regenerative ability to repair damaged myocardium by itself. Cellular cardiomyoplasty was introduced to compensate for this lack of regenerative ability by delivering viable cells to distressed myocardium that has almost no functional cells (Figure 1). To develop this attractive method, many kinds of cells were implanted into small animal or large animal models through various routes. Based on the results of these experiments, several clinical trials have already been performed, and revealed the feasibility and efficacy of this technique. Although the mechanisms for the functional improvement after cellular cardiomyoplasty have not been completely elucidated, most researchers believe that its efficacy mainly depends on the paracrine effect of cytokines, because the incidence of transplanted cell differentiation to cardiomyocytes is low, there is no contractile function in most of the implanted cells [1], and the implanted cells represent only a small fraction of the LV mass [2].

\subsection{Skeletal Myoblasts}

\subsubsection{Experimental Achievements}

Unlike heart muscle, skeletal muscle has its own regenerative system. As soon as skeletal fibers are injured, skeletal myoblasts under the basal membrane of the skeletal fibers are mobilized and fuse with neighboring 


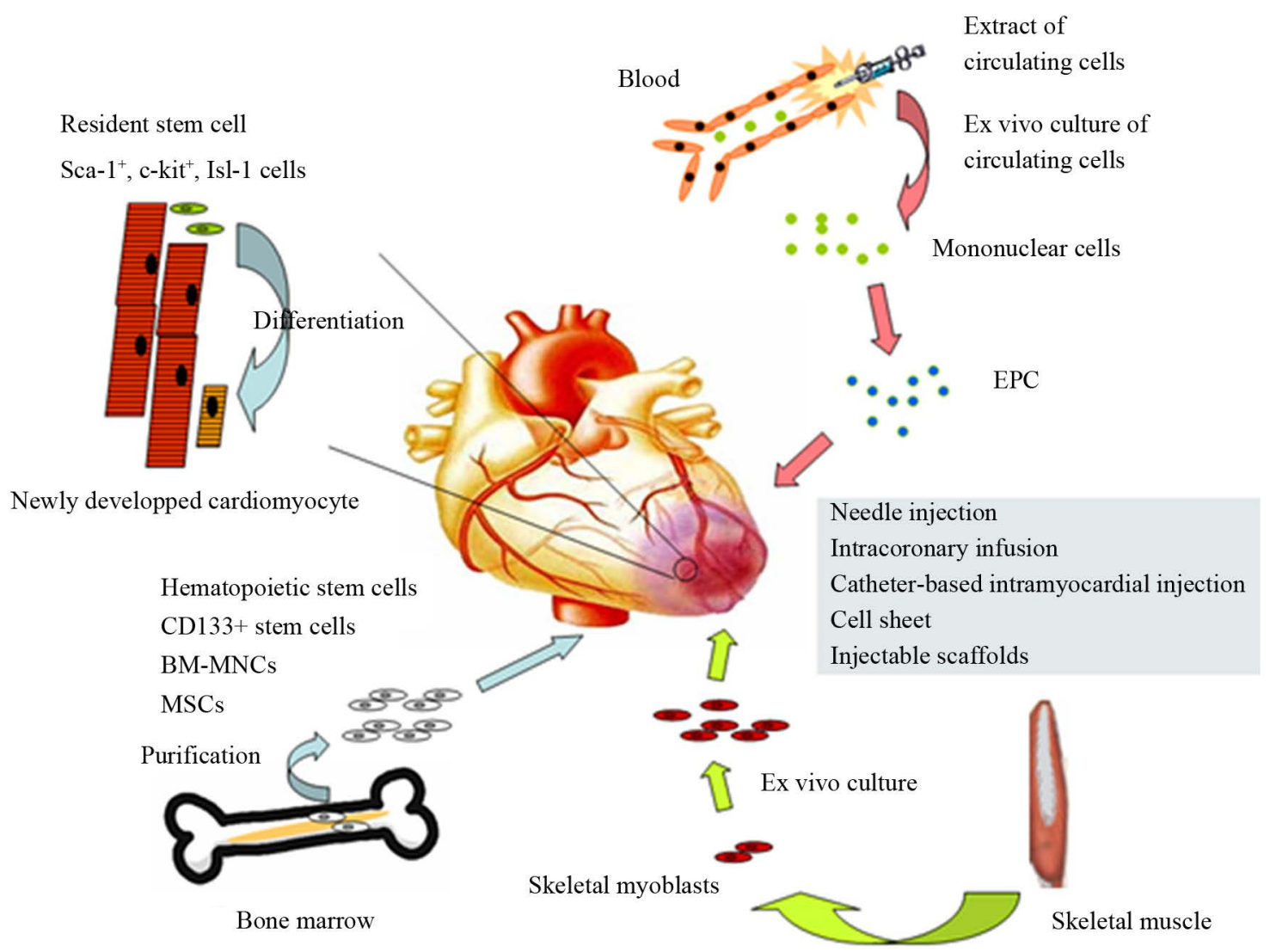

Figure 1. Cell sources for myocardial regeneration. Current clinical trials include the transplantation of skeletal myoblasts, bone marrow mononuclear cells, mesenchymal stem cells, or circulating progenitor cells. Cells used in experimental studies are resident stem cells and hematopoietic stem cells. There are various kinds of cell delivery routes, such as needle injection, intracoronary infusion, catheter-based intramyocardial injection, and cell sheet.

myoblasts, leading to regenerated, functional skeletal muscle. To exploit their self-regenerative capacity, myoblasts were implanted into the distressed myocardium, which has no regenerative system. The viability of the transferred myoblasts and their affinity for the myocardium were studied, and many experiments on the cell survival, differentiation to cardiomyocytes, and electrical coupling with recipient myocytes were performed to examine the effectiveness of myoblast implantation.

Implanted myoblasts engrafted to cryoinjured dog myocardium [3,4] prevented LV remodeling and improved cardiac performance $[5,6]$. The implanted myoblasts did not transdifferentiate into cardiomyocytes, showing a mature skeletal muscle phenotype [7]. Mature skeletal muscle grafts in the distressed myocardium had no connexin43 or N-cadherin, indicating they did not undergo electrical coupling with the host myocardium in vivo [8]. However, a low incidence of myoblast fusion with cardiomyocytes was observed [9], and a small number of these fused cells showed connexin43 expression [10]. Suzuki et al. reported that connexin43-overexpressing myoblasts formed functional gap junctions, suggesting the potential for synchronous contraction with host myocytes
[11]. However, implanted myoblasts isolated from the recipient myocardium could not contract synchronously with host cardiomyocytes [12]. Myoblasts are thought to be the best candidate for cardiomyogenesis in the clinical setting, because cardiomyocytes cannot be cultured for clinical use, and only myoblasts can differentiate to muscle. However, implanted myoblasts can be isolated from the host myocardium electrically in vivo, indicating that they do not differentiate, and the cardiomyogenesis in the failing heart is quite incomplete.

\subsubsection{Clinical Achievements}

Despite the lack of affinity of implanted myoblasts for the host myocardium, many papers have reported functional improvement in small animal and large animal models following myoblast transplantation, leading to clinical applications. This technique is attractive because of its high resistance to ischemia and use of autologous cells [13], even though the mechanisms underlying its effects are still unclear.

Several groups reported the clinical efficacy of myoblast transplantation through needle injection [14-18] or catheter [19] (Table 1). These clinical studies indicated 


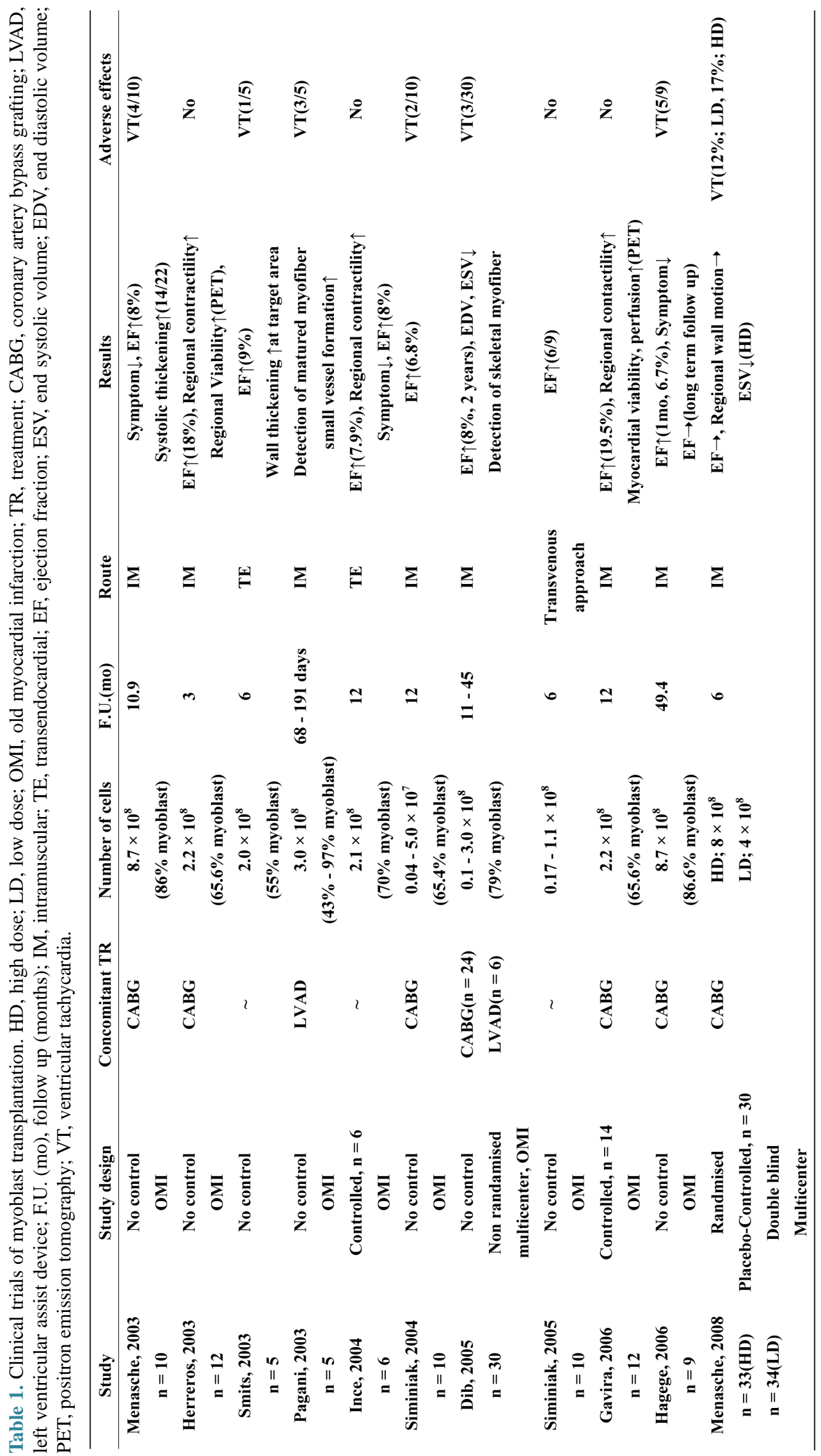


its feasibility by establishing human myoblast cell culture methods in Good Manufacturing Practice-approved facilities and procedures for injecting cells into the human myocardium [13]. Two papers successfully identified mature myofibers in the human myocardium after transplantation $[17,20]$, but its efficacy needs to be further investigated because of the absence of control groups and concomitant coronary bypass surgery in many studies. Although the incidence of ventricular tachycardia after engrafting was high, occurring in 4 out of 10 patients [15] and 1 out of 5 patients [19], a causal relationship between the myoblasts and ventricular tachycardia remains unknown. To evaluate its efficacy and arrhythmogenicity, Menasche et al. performed a multicenter, randomized, placebo-controlled, double-blind study and revealed a high incidence of early postoperative arrhythmic events and prevention of LV remodeling with a highdose cell injection, although no improvement in global systolic function was seen [21].

Recently myoblast sheet implantation technique in human DCM and ICM has already been introduced to clinical application. However, to prove its therapeutic effectiveness, a multicenter, randomized, placebo-controlled, double-blind study should be performed.

\subsection{Bone Marrow Cells}

\subsubsection{Experimental Achievements}

Progenitor cells within bone marrow cells (BMCs) play a large role in the regeneration of damaged skeletal muscle [22], and this exciting finding encouraged researchers to explore the regeneration ability of BMCs in the failing myocardium. The potential ability of BMCs to differentiate to cardiomyocytes in vivo has been shown in several reports. Orlic et al. sorted lineage-negative (Lin-) and c-kit+ BMCs by fluorescence-activated cell sorting from mice constitutively expressing enhanced green fluorescent protein (EGFP), and transplanted these cells into an infarcted area. Surprisingly, newly formed cardiomyocyte tissue was regenerated in approximately $68 \%$ of the infarcted area, and these transdifferentiated EGFP-positive cardiomyocytes expressed cardiomyocyte-specific markers, such as cardiac myosin and several transcription factors, and improved cardiac performance [23,24]. This discovery supported the idea of myocardial regeneration by multipotential BM stem cells. The work of Jackson et al. suggested that hematopoietic stem cells (HS cells; a component of BM stem cells that is CD34+, the so-called side population cells) can differentiate into cardiomyocytes. These researchers implanted HS cells from Rosa26 mice that constitutively expressed betagalactosidase into lethally irradiated mice and made an infarction model of these mice. The transplanted betagalactosidase-positive HS cells migrated to the periin- farcted region, and were identified as newly differentiated cardiomyocytes at a prevalence of approximately $0.02 \%$, and as endothelial cells at 3.3\%, of all myocytes [25]. Although this report is exciting, the incidence of differentiation to cardiomyocytes was revealed to be quite low, unlike the above-mentioned study by Orlic et al. Another exciting study appeared to show that BMCs can differentiate into cardiomyocytes in human samples. Deb et al. examined female uninjured hearts from patients who had undergone male bone marrow transplantation, and detected approximately $0.23 \% \mathrm{Y}$ chromosome-positive cardiomyocytes by the FISH method. This study also indicated that the transdifferentiation to cardiomyocytes was very rare. Several groups have since examined the reproducibility of BMC differentiation to cardiomyocytes, motivated by these promising results.

However, Murry et al. introduced a new system for determining cell transdifferentiation to cardiomyocytes using genetic methods without a histological detection system, and clearly showed that no HS cells differentiated into cardiomyocytes after their transplantation to infarcted myocardium [1]. Moreover, Balsam et al. failed to reproduce the transdifferentiation of Lin- and c-kit+ bone marrow cells to cardiomyocytes in vivo [26]. Several groups clearly revealed that BMCs can spontaneously fuse with other cells, such as liver cells [27], cardiomyocytes, and Purkinje neurons [28], and that the BMCs can obtain the phenotype of the cells with which they have fused [29]. This special ability of BMCs to undergo cell fusion can explain the apparent transdifferentiation of BMCs to cardiomyocytes [30]. In addition, Laflamme et al. pointed out that the apparent transdifferentiation to cardiomyocytes evaluated by histological detection systems was owing to misleading artifacts in confocal microscopy. in his review [31]. However, Kajstura et al. [32] and Yoon et al. [33] offered counterarguments to the lack of HS cell transdifferentiation to cardiomyocytes. Thus, there is presently no consensus about whether HS cells transdifferentiate to cardiomyocytes in vivo.

BMCs contain two components, HS cells and mesenchymal stem cells (CD 34-, present in the bone marrow stroma). Several reports revealed that mesenchymal stem cells (MSCs) can differentiate into cardiomyocytes in vitro under certain conditions [34-36], while the incidence of their transdifferentiation to cardiomyocytes in vivo is quite low $[37,38]$. In spite of the low incidence of differentiation to cardiomyocytes and small amount of newly developed cardiomyocyte tissue, MSC [39] implantation induces a marked improvement in cardiac function.

\subsubsection{Clinical Achievements}

In spite of the low evidence for BMC differentiation to cardiomyocytes and unclear mechanism, intracoronary 
bone marrow mononuclear cell (BMMC) implantation was quickly introduced to the clinical setting, mainly for acute myocardial infarction, because methods were already well-established for BMC aspiration in hematological treatments, and there was no need to perform cell culture. Generally speaking, although the trials for BMMC implantation revealed its safety and feasibility, its effectiveness varied. This variability may have been owing to differences in the heterogeneous population of BMCs in each study, the number of cells transferred, and the time after acute myocardial infarction (AMI) that treatment was performed.

Several clinical trials of BMC implantation for AMI revealed its safety, feasibility, and efficacy. All of the studies used the intracoronary injection method (Table 2). Five randomized, controlled studies have been reported. The BOOST randomized controlled clinical trial for 60 AMI patients (BMCs, 30 patients; Control, 30 patients) was done in 2004 and showed that the global systolic function measured by magnetic resonance imaging (MRI) with BMC treatment was significantly improved at the 6-month follow-up, compared with the sham-injected controls [40]. In 2006, the same group checked the long-term results at 18 months after implantation in a randomized, controlled study, and observed no significant improvement in the left ventricular ejection fraction (LVEF), despite the significant improvement seen at 6 months [41]. However The Balance study revealed that BMC implantation induce significant improvement of cardiac performance and prolong survival rate 60 months after implantation [42]. Although this is very exciting study reporting the long-term results after BMC implantation in AMI, studies which comment about long term results are not so many and these studies are controversial. So further studies may be needed to elucidate long term results after BMC implantation. In 2006, the first randomized, double-blind, placebo-controlled study was reported in 67 AMI patients (BMCs, 33 patients; Placebo, 34 patients) and demonstrated a significant reduction in myocardial infarction size and a better recovery of regional systolic function, but no improvement in global function, at 4 months after implantation, with no complications [43]. Recently, the largest, randomized, placebo-controlled, multicenter study was performed using 204 patients (BMCs, 101 patients; Placebo, 103 patients) with AMI. This encouraging study revealed that the LV systolic function was significantly improved at 4 months after implantation compared with its pre-treatment value, and this improvement was better in the BMC group than in the placebo-control group, and significantly fewer adverse events were seen in the BMC group [44]. In contrast to the positive results obtained in other studies, ASTAMI, a randomized controlled study using 100 AMI patients (BMCs, 50 patients; Control, 50 pa- tients) revealed no significant difference in the LVEF, end-diastolic volume, or infarct size at 6 months between the BMC implantation group and the control group, as measured by electrocardiogram-gated single-photon-emission computed tomography (SPECT), MRI, and echocardiography [45]. In summary, although there are some discrepancies in the efficacy in BMC implantation for the short-term results, its safety and feasibility were clearly established. Further study is needed to before we can assess the results of BMC implantation in the long term.

In several studies, BMMCs were transplanted via transendocardial injection into patients with chronic myocardial infarction (Table 3). In one prospective, nonrandomized, open-label study, BMMCs were delivered via NOGA catheter into patients with chronic ischemic heart disease (treatment, 14 patients; control, 7 patients). This study showed improvement of the ejection fraction (EF) and myocardial blood flow compared with the control [46], and at the 12-month follow-up, the BMMC-treated patients demonstrated better myocardial perfusion and exercise capacity [47]. Fuchs et al. implanted BMMCs into 10 patients with chronic ischemic heart disease without controls, and showed improvements in the coronary flow and angina score compared with the pre-treatment value, but no improvement of EF [48]. Tse et al. showed the improvement of symptoms, myocardial perfusion, and regional function, but no improvement in global systolic function at 3 months compared with the pre-treatment value in 8 patients after BMMC implantation. Recently, a randomized, single-center study using 92 patients with mild heart failure caused by chronic myocardial infarction (at least 3 months previously) was performed. Improved regional and global systolic function was seen in the BMC-implantation group after 3 months compared with controls treated with circulating blood cells, and with the pre-treatment values [49]. A previous report [50] demonstrated that circulating blood cells have the same potency as BMCs for treating AMI, but for chronic-phase myocardial infarction, the circulating blood cells have no effect on myocardial regeneration. A precise evaluation of the effect of BMMC implantation for chronic ischemic heart disease still awaits a multicenter, randomized, placebo-controlled, and double-blind study.

Abdel-Latif et al. performed a meta-analysis, which included eighteen studies and 999 patients with ischemic heart disease. They concluded that BMC transplantation has stable effects that include improving the EF, reducing the infarct scar size, and reducing the LV end-systolic volume in patients with AMI and chronic MI compared with controls [51]. In addition, a recent review by Kloner and colleagues demonstrated that the benefits of cell therapy were as good as the currently recommended therapies: reperfusion, beta blockers and ACE inhibitors [52]. 


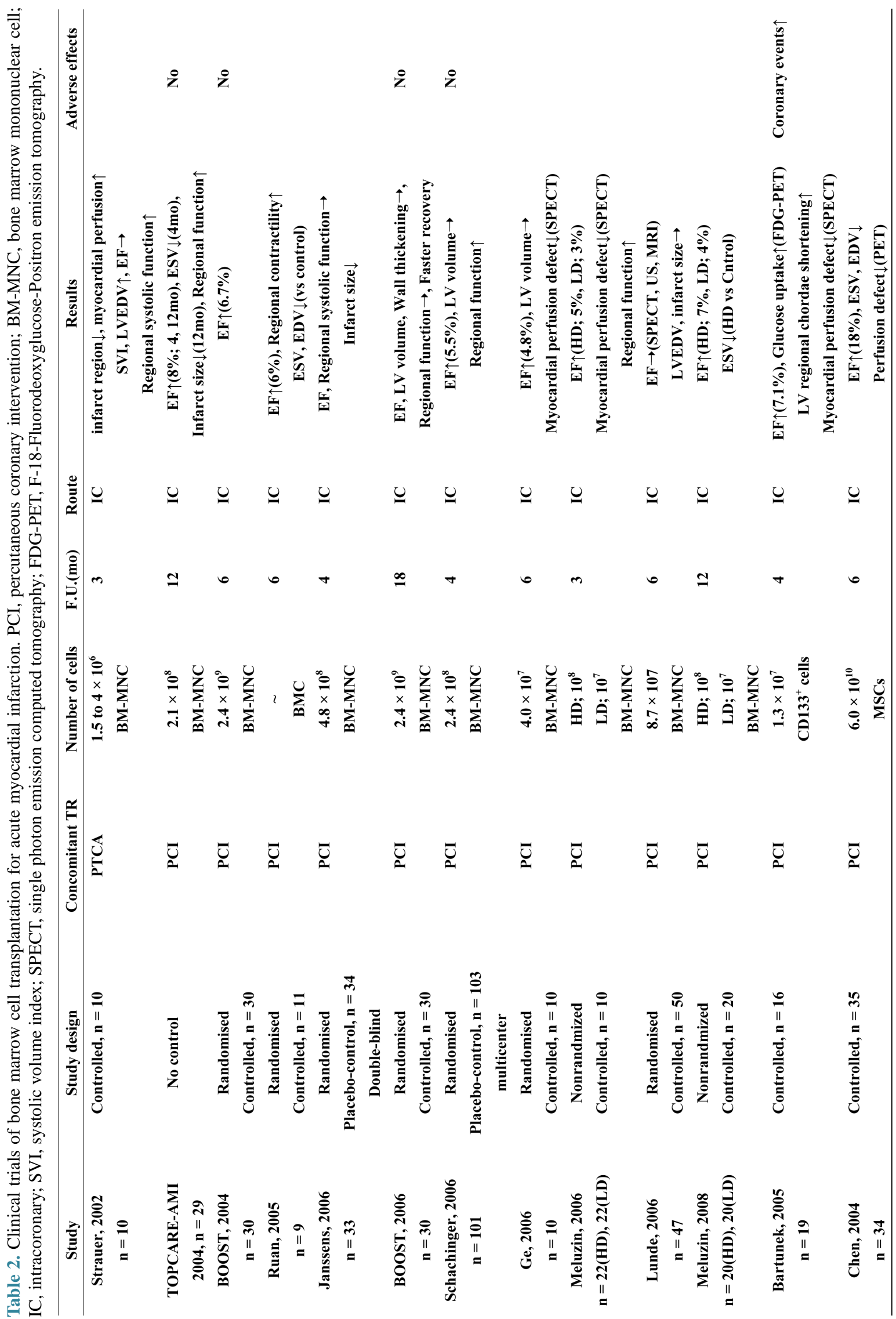




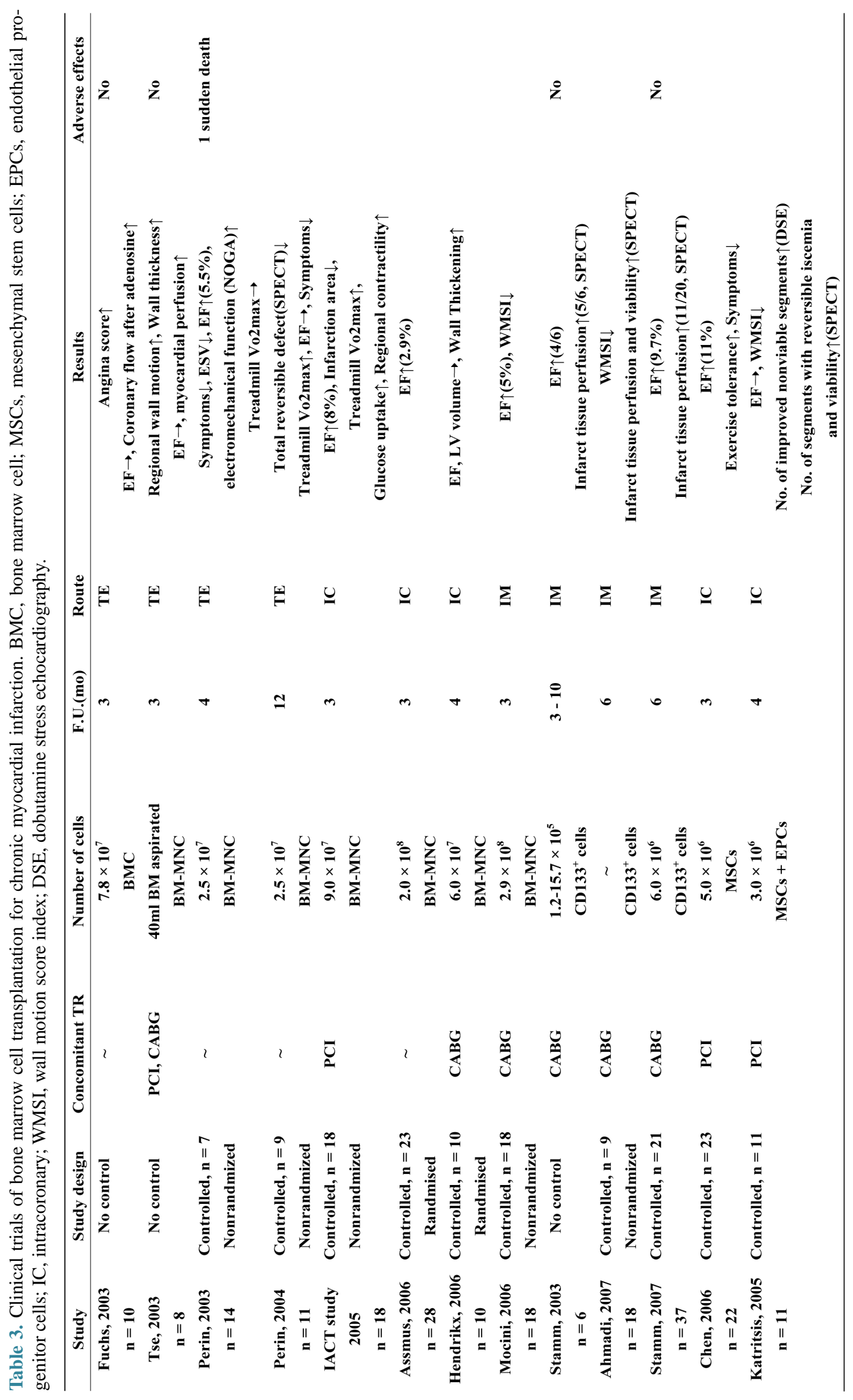


CD133+ cells, which include hematopoietic stem cells, are reported to have angiogenic potential [53]. Because of this potential angiogenic capacity, CD133+ cell transplantation was tested clinically to treat ischemic myocardium. These cells were introduced into six patients who had old myocardial infarction (OMI) concomitant with coronary artery bypass grafting (CABG), and caused improved global systolic function and infarct tissue perfusion compared with the pre-treatment values [54]. However, this study had no control group. In their next clinical CD133+ cell transplantation study, these researchers reported that the combination of CABG and CD133+ cell transplantation showed significant improvement in LVEF and better perfusion of the infarcted myocardium compared with $\mathrm{CABG}$ alone, and that the procedure was safe [55]. For AMI, Bartunek et al. performed intracoronary CD133+ cell implantation in nineteen AMI patients and revealed a significant improvement in LVEF and reduction in the perfusion defect at 4 months, with an increased incidence of coronary events [56].

Regarding clinical MSC transplantation, two randomized and controlled studies have been reported. MSC transplantation was found to have efficacy for cardiac performance and exercise tolerance in both AMI [57] and OMI patients [58]. However, these analyses were incomplete, and a large study of appropriate design is still needed to clarify its effectiveness.

\subsection{Other Clinical Studies in Cellular Cardiomyoplasty}

While clinical applications using BMCs and myoblasts are still being developed, a second wave of clinical applications is underway using circulating progenitor cells (CPCs), CD34+ cells, MSCs, the combination of MSCs and endothelial progenitor cells, and the combination of BM-MNCs and myoblasts (Table 4).

Recently, several reports showed that bone-marrow derived CPCs, which were demonstrated to differentiate into endothelial progenitor cells (EPCs) [59], can promote neoangiogenesis in animal ischemic myocardium models [60]. These findings encouraged clinicians to apply CPC transplantation clinically. CPC transplantation has the great advantage of being less invasive in clinical settings, requiring just peripheral blood apheresis, in contrast to BMC and myoblast transplantation. Several protocols for CPC transplantation through intracoronary infusion have been reported, and they can be divided into treatments with granulocyte colony-stimulating factor (G-CSF) and those without. The TOPCARE-AMI Trial in 2004 for AMI patients without a control showed significant improvement in the LVEF, an attenuation of LV dilatation, and reduced infarct size at the one-year follow-up [50]. Tatsumi et al. performed an open-label, nonrandomized, controlled clinical trial for AMI patients treated with CPC implantation without using G-CSF and cell expansion, and revealed a significant increase in the LVEF and regional systolic performance at 6 months without any adverse clinical events [61]. The first randomized, double blind, and placebo-controlled study on CPC transplantation demonstrated an improvement in coronary flow reserve, decline in the number of hibernating segments, and an increase in LVEF at 3 months after transplantation, indicating that CPC transplantation was effective for OMI patients [62]. Contrary to this finding, The MAGIC cell-3DES randomized and controlled trial revealed that, although CPC transplantation had a positive impact on cardiac performance in AMI patients, it had no effect on OMI patients [63]. Assumus et al. supported these results in his paper [49]. Enriched EPCs (CD34+ stem cells) collected from the peripheral blood were transplanted into patients with intractable angina through transendocardial injection in a doubleblind, randomized, placebo-controlled, and dose-escalating study, and revealed its safety and feasibility [57]. Although several clinical studies of CPC transplantation confirmed its safety and feasibility, a multicenter, randomized, placebo-controlled, and double-blind study is still needed for an accurate evaluation of its efficacy and long-term results.

Clinical cellular cardiomyoplasty as mentioned above is mainly used to cause angiogenesis rather than myogenesis, because the implanted cells have little capacity to differentiate into cardiomyocytes. Two studies reported the induction of both angiogenesis and myogenesis in the failing heart by the combined transplantation of angiogenesis- and myogenesis-inducing cells. A combination cell therapy using MSCs capable of differentiating into cardiomyocytes and EPCs that induce angiogenesis applied through intracoronary transplantation improved the regional systolic performance and regional blood perfusion but did not improve the global systolic function [64]. This result was disappointing, because this study aimed to induce both myogenesis and angiogenesis. The results may have been limited because MSCs have little ability to differentiate into cardiomyocytes, which was well supported by basic experiments, so the combined cell transplantation may induce only angiogenesis. Miyagawa et al. implanted both BMMCs and skeletal myoblasts into patients with severe heart failure caused by chronic ischemic heart disease under a left ventricular assist device (LVAD), and observed improvements in the global systolic and diastolic function in a series of LVAD-off tests [65]. This clinical therapy in which these two cell types were transplanted together into the ischemic myocardium probably enhanced the secretion of growth factors such as hepatocyte growth factor, rather than inducing angiogenesis and myogenesis [66]. 


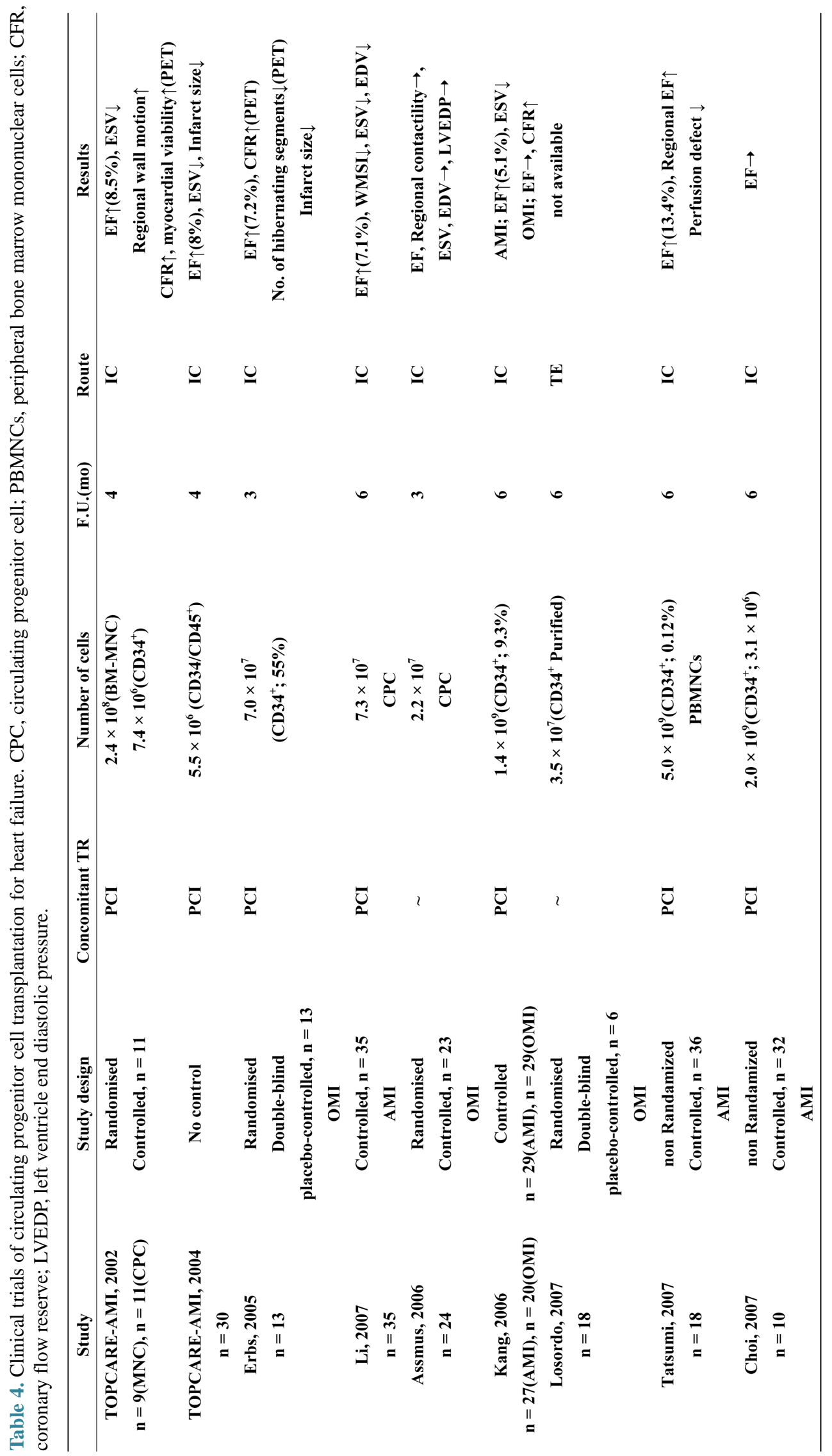




\subsection{Paracrine Effect of Cytokines after Cellular Cardiomyoplasty}

Given that the incidence of stem-cell differentiation to cardiomyocytes is quite low, as described above, why does stem-cell transplantation show beneficial effects on heart failure? This discrepancy can be explained by the fact that these cells provide paracrine growth factors. Takahashi et al. reported that various cytokines (VEGF, IL1beta, PDGF, and IGF-1) are highly detected in the supernatant of BM-MNCs under hypoxic conditions, and injection of the cytokine-rich supernatant into an AMI rat model increased the microvessel density, significantly improved in cardiac function, and inhibited cardiomyocyte apoptosis [67]. Uemura et al. reported that preconditioned BM stem cells that can secrete high levels of cell survival factors such as Akt and eNOS could prevent apoptosis in cardiomyocytes around the site of infarction [68]. Moreover, Kamihata et al. revealed that transplanted BM-MNCs can improve angiogenesis by secreting cytokines with angiogenic potential and by being incorporated into neocapillaries [69]. However, the angiogenesis promoted through the release of several cytokines, such as VEGF and bFGF, has a greater impact on the formation of neocapillaries than did the direct incorporation of cells into new vessels [70]. The bone marrow stromal cell conditioned medium, which includes arteriogenic cytokines, promoted the proliferation and migration of endothelial cells and smooth muscle cells [71]. Although cytokine release from transplanted cells is one of the mechanisms for myocardial regeneration in cellular cardiomyoplasty, the degree of their contribution to myocardial regeneration is not clearly known, and it may depend on the severity of the diseased myocardium.

Many researchers then sought to exploit this cytokine effect, and introduced the transplantation of cytokineoverexpressing cells to enhance the therapeutic effects of the original cells used in myocardial regeneration strategies. Askari et al. transplanted Stromal cell derived factor 1 (SDF-1)-overexpressing fibroblasts into an ischemic cardiomyopathy model, which enhanced stem-cell homing to the injured myocardium [72]. SDF-1 released from a myoblast sheet could mobilize CXCR4+ cells to the injured myocardium [2]. Moreover, stem-cell mobilization and homing therapy by G-CSF was introduced to another myocardial regeneration treatment as an alternative to cellular cardiomyoplasty [73,74].

If stem cells play only act as growth factor suppliers, allogenic stem cells that can supply growth factors to the diseased myocardium may regenerate the failing heart. Based on this theory, Imanishi et al. introduced allogenic MSCs, which have low immunogenicity [75], to treat acute myocardial infarction and observed that they triggered the secretion of vascular endothelial growth factor
(VEGF) and preserved cardiac performance, accompanied by angiogenesis [76]. This strategy has the advantage of being applicable to emergent cases in clinical settings, but the possible disadvantage of having no effect on chronic heart failure. Some unique approaches using both myoblasts and BMCs to regenerate distressed myocardium have been reported. Memon et al. demonstrated that the implantation of both myoblasts and BMCs enhanced the secretion of growth factors and improved cardiac performance compared with each singlecell therapy [66].

\subsection{Mechanisms of Myocardial Regeneration in Cellular Cardiomyoplasty in the Failing Heart}

We can speculate that the following mechanisms underlie the myocardial regeneration induced by cellular cardiomyoplasty in the failing heart, but these pathways also affect each other, causing the mechanisms to be complicated (Figure 2).

1) Transplanted stem cells differentiate into cardiomyocytes, leading to improved regional systolic and diastolic function. However, this pathway is not crucial, because the incidence of transdifferentiation to cardiomyocytes is quite low.

2) Cytokines released from the transplanted stem cells have effects that promote healing.

- Angiogenic cytokines (VEGF, HGF) induce angiogenesis, which can supply blood and nutrition to the transplanted cells and ischemic host cardiomyocytes.

- Anti-cell-death cytokines (Akt, eNOS etc.) prevent the apoptosis of cardiomyocytes in infarcted and periinfarcted regions.

- Stem-cell mobilizing cytokines (SDF-1 etc.) can induce stem-cell homing from the BM, and the migrated stem cells can become incorporated into capillaries.

- Antifibrotic cytokines may regulate the progression of fibrosis in the failing heart.

3) Transplanted stem cells are incorporated into capillaries by differentiating into endothelial cells and smooth muscle cells.

4) The thickening of the thin LV wall by newly supplied of elastic cells reduces wall tension, preserves LV geometry, and improves the elasticity in rigid scar tissue.

\section{FUTURE PROSPECTS}

\subsection{Pluripotent Stem Cells}

Although recently many reports depicted that stem cells such as c-kit positive [23], sca-1 positive cells [77], Human Amniotic Fluid Stem Cells (hAFSC) [78], Adipocyte Derived Stem Cells [79], Cardiospheres [80], or 


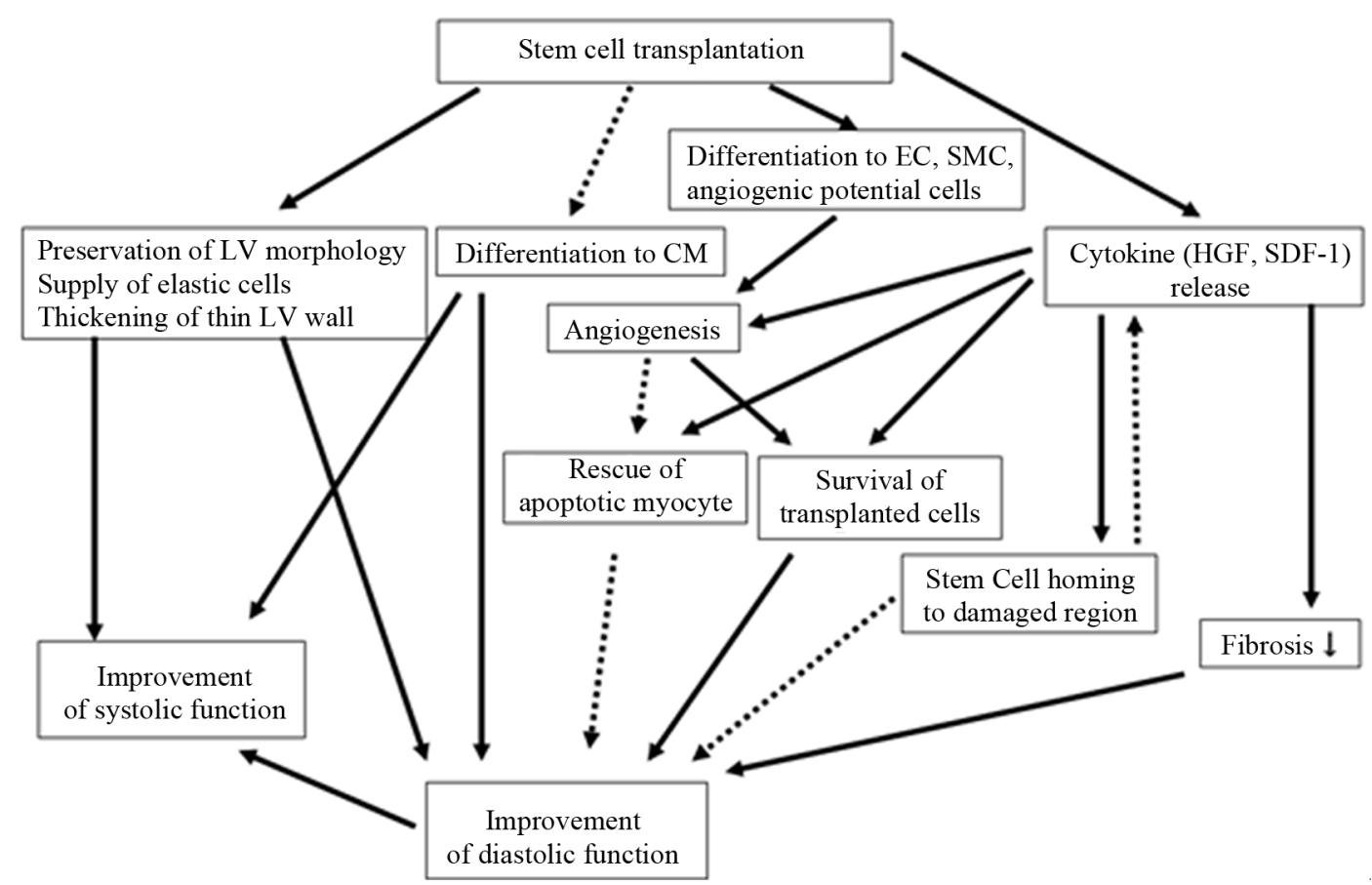

Figure 2. Mechanisms of stem cell therapy for heart failure. The differentiation of transplanted stem cells into cardiomyocytes may provoke the improvement of regional systolic and diastolic function. However, this mechanism has little impact on cardiac repair, because the incidence of transdifferentiation to cardiomyocytes is quite low. Cytokines released from the transplanted stem cells induce angiogenesis, which can support survival of the transplanted cells and reverse the ischemia in the failing heart, prevent cell death, and mobilize stem cells to induce cardiac repair. Some of the transplanted stem cells differentiate into smooth muscle cells and endothelial cells and become incorporated into capillaries. Moreover, the transplanted stem cells can increase elasticity and thickening in the rigid thin scar tissue, leading to improved diastolic function and the preservation of LV geometry. These pathways affect each other, causing the mechanisms to be complicated.

mecenchymal stem cells [81] has a capability of differentiation to cardiomyocyte and can express some structural proteins such as actin or troponin, these cells cannot contract spontaneously in vitro and it is unknown whether these cells have same micro structures as cardiomyocytes. If these cells are implanted to damaged myocardium, these cells may not offer contractile force directly to impaired heart but affect the cardiac performance probably by cytokine paracrine effect. Almost all reports concerning about cellular cardiomyoplasty showed improvement of cardiac performance and symptoms mainly via angiogenesis induced by angiogenic cytokines. But some groups introduced myogenic progenitor cells such as c-kit positive cells or spheroid cells and these cells are introduced to clinical trials. One exciting clinical protocol was reported that c-kit positive cells are transplanted to chronic ischemic myocardium via trans-catheter concomitant with bypass surgery and this cellular cardiomyoplasty significantly improved cardiac performance after cellular therapy. These c-kit positive cells demonstrated myogenic differentiation but differentiated cells only expressed some myogenic structural proteins and are unknown about synchronous contraction ability in vitro and vivo. Further studies are needed to elucidate whether these cardiomyogenic cells may impact on cardiac performance via paracrine effect or cardiomyogenesis.

So in regenerative medicine, stem cells which can contract spontaneously and have a capability of integration with myocardium via connexin 43 or cell-cell adhesive system. One of candidates in contractile cells may be Embryonic stem cells (ES cells) or Induced puluripotent stem (iPS) cells derived cardiomyocytes.

60 billion cells, which can differentiate over two hundred kind of cells, consist of Human body and these cells are components of tissues (skin, bone, and muscle) and organs (stomach, liver, and pancreas). Although, generally speaking, differentiation of cells in higher forms of life is irreversible, only a fertilized egg has a capability of puluripotency. ES cells are isolated from inner cell clusters which were recognized when a fertilized egg grows to germinal vesicle by repeated proliferation and this ES cells have capability of puluripotency [82].

The methods of differentiation to cardiomyocytes in ES cells have been already established and some papers reported its therapeutic effectiveness for heart failure [83]. But in the consideration of clinical application, many 
drawbacks exists in this field. One of the problems is how to culture a large amount of cells in cell processing center without DNA damage. We speculate that over $10^{8}$ cells are needed to repair the human damaged myocardium, but culture methods have not been examined in world wide. Second problem is how to avoid teratoma formation after implantation. There are no answers to elucidate these problems.

Although ES cells have ethical problem for clinical application, iPS cells have been developed to avoid ethical problems which ES cells have. Yamanaka reported that somatic stem cells which are transfected with four factors (Oct3/4, Sox2, Klf4, c-Myc) have a character of ES like pluripotent stem cells [84-86]. Same as ES cells, methods of differentiation to cardiomocytes have been already established and its therapeutic efficacy for heart failure has been reported [83]. But some problems are exist for clinical application as mentioned above in ES cells. As for iPS cells, some papers reported that cardiomyocytes differentiated from iPS cells are systematically selected form undifferentiated iPS cells by specific marker of mitochondria [87]. And another paper reported that $\mathrm{T}$ cell derived iPS cells can differentiate to cardiomyocytes and these cells might not change to teratoma after vivo implantation [88]. Many challenges have already been tried to avoid teratoma formation, but culture method of a large amount of cells has not been established. But special cell delivery methods such as cell sheet or combination with some angiogenic or antiapoptotic drugs might help to solve drawbacks of cell numbers which fail to improve cardiac function in the damaged heart [89]. Moreover retrovirus, trasnfection tool of 4 factors, may not be safe for clinical application. So safe transfection method of 4 factors may be needed for clinical application. To aim of clinical application, several papers reported that iPS cell derived cardiomyocyte sheet induced functional recovery in large animal [90] or small animal heart failure model [91] and these implanted cells were survived in myocardium. Proof of concept has already been proven in pre-clinical study, so clinical application of iPS cell derived cardiomyocytes will be started after verification of safety.

Recently Ieda et al. reported that fibroblasts can directly differentiate to cardiomyocytes with combination of several factors and with direct reprogramming [92]. This technology is innovated, but some issues (how about differentiation rate to cardiomyocytes? Do differentiated cardiomyocytes poses microstructure of native cardiomyocyte? etc.) should be elucidated.

\subsection{Cell Delivery Methods}

It is natural to discuss which cell source is best for the regeneration of damaged myocardium. However cell delivery method is also crucial for the cell therapy to en- hance its therapeutic effects. Many papers reported that various kinds of cell delivery method, such as needle injection, trans coronary artery injection, trans coronary sinus injection, scaffolds containing cells, and cell sheet technique, have been reported to be effective to repair the damaged heart. Especially cell sheet implantation is reported to be superior to needle injection method in experimental study. In concerning of cell delivery methods, combination of some angiogenic drugs [93] or vascular rich tissue such as omentum with cells may be next step to enhance therapeutic effectiveness in cell based myocardial regeneration therapy [89].

Moreover repeated implantation of skeletal myoblast has a capability of the improvement of cardiac performance in a swine model of chronic myocardial infarction [94]. So in clinical setting repeated cell implantation may have some impacts on the enhancement of therapeutic effect in cell transplantation, but coronary artery embolism may be happen in this treatment.

\section{CONCLUSIONS}

We have summarized the recent advances in cellular cardiomyoplasty in both the laboratory and the clinic. Although many kinds of cells with the capacity to differentiate to cardiomyocytes have been reported, few stem cells can probably actually differentiate to cardiomyocytes. However, a cardiomyocyte cell source that is applicable to clinical settings is critical for treating severe heart failure, so researchers should continue to look for stem cells that can differentiate into cardiomyocytes.

We surveyed many encouraging clinical studies, which used many different kinds of cells, and found that almost all of the cell types had some effects on cardiac performance in the damaged heart. The important questions to ask when applying these cell-based therapies to clinical situations are:

1) Which cells have the greatest impact on myogenesis, angiogenesis, and cardiac performance?

2) Is a heterogeneous cell population or purified cell type better to regenerate the failing heart?

3) Which stage of heart failure can cellular cardiomyoplasty repair?

Genuine myocardial regeneration involves the induction of cardiomyogenesis and angiogenesis by smooth muscle cells and endothelial cells in the completely distressed myocardium. To reach this goal will require the discovery of new cells that can differentiate into cardiomyocytes, better cell delivery methods that enable as many functional cells as possible to reach the failing heart, and new ways to promote functional vasculogenesis.

\section{REFERENCES}

[1] Murry, C.E., Soonpaa, M.H., Reinecke, H., Nakajima, H., 
Nakajima, H.O., Rubart, M., Pasumarthi, K.B., Virag, J.I., Bartelmez, S.H., Poppa, V., Bradford, G., Dowell, J.D., Williams, D.A. and Field, L.J. (2004) Haematopoietic stem cells do not transdifferentiate into cardiac myocytes in myocardial infarcts. Nature, 428, 664-668. http://dx.doi.org/10.1038/nature02446

[2] Memon, I.A., Sawa, Y., Fukushima, N., Matsumiya, G., Miyagawa, S., Taketani, S., Sakakida, S.K., Kondoh, H., Aleshin, A.N., Shimizu, T., Okano, T. and Matsuda, H. (2005) Repair of impaired myocardium by means of implantation of engineered autologous myoblast sheets. The Journal of Thoracic and Cardiovascular Surgery, 130, 1333-1341. http://dx.doi.org/10.1016/j.jtcvs.2005.07.023

[3] Marelli, D., Desrosiers, C., el-Alfy, M., Kao, R.L. and Chiu, R.C. (1992) Cell transplantation for myocardial repair: An experimental approach. Cell Transplantation, 1, 383-390.

[4] Chiu, R.C., Zibaitis, A. and Kao, R.L. (1995) Cellular cardiomyoplasty: Myocardial regeneration with satellite cell implantation. The Annals of Thoracic Surgery, 60, 12-18.

[5] Jain, M., DerSimonian, H., Brenner, D.A., Ngoy, S., Teller, P., Edge, A.S., Zawadzka, A., Wetzel, K., Sawyer, D.B., Colucci, W.S., Apstein, C.S. and Liao, R. (2001) Cell therapy attenuates deleterious ventricular remodeling and improves cardiac performance after myocardial infarction. Circulation, 103, 1920-1927. http://dx.doi.org/10.1161/01.CIR.103.14.1920

[6] Taylor, D.A., Atkins, B.Z., Hungspreugs, P., Jones, T.R., Reedy, M.C., Hutcheson, K.A., Glower, D.D. and Kraus, W.E. (1998) Regenerating functional myocardium: Improved performance after skeletal myoblast transplantation. Nature Medicine, 4, 929-933. http://dx.doi.org/10.1038/nm0898-929

[7] Reinecke, H., Poppa, V. and Murry, C.E. (2002) Skeletal muscle stem cells do not transdifferentiate into cardiomyocytes after cardiac grafting. Journal of Molecular and Cellular Cardiology, 34, 241-249. http://dx.doi.org/10.1006/jmcc.2001.1507

[8] Reinecke, H., MacDonald, G.H., Hauschka, S.D. and Murry, C.E. (2000) Electromechanical coupling between skeletal and cardiac muscle. Implications for infarct repair. The Journal of Cell Biology, 149, 731-740. http://dx.doi.org/10.1083/jcb.149.3.731

[9] Reinecke, H., Minami, E., Poppa, V. and Murry, C.E. (2004) Evidence for fusion between cardiac and skeletal muscle cells. Circulation Research, 94, e56-60. http://dx.doi.org/10.1161/01.RES.0000125294.04612.81

[10] Rubart, M., Soonpaa, M.H., Nakajima, H. and Field, L.J. (2004) Spontaneous and evoked intracellular calcium transients in donor-derived myocytes following intracardiac myoblast transplantation. Journal of Clinical Investigation, 114, 775-783.

[11] Suzuki, K., Brand, N.J., Allen, S., Khan, M.A., Farrell, A.O., Murtuza, B., Oakley, R.E. and Yacoub, M.H. (2001) Overexpression of connexin 43 in skeletal myoblasts: Relevance to cell transplantation to the heart. The Journal of Thoracic and Cardiovascular Surgery, 122, 759-766. http://dx.doi.org/10.1067/mtc.2001.116210
[12] Leobon, B., Garcin, I., Menasche, P., Vilquin, J.T., Audinat, E. and Charpak, S. (2003) Myoblasts transplanted into rat infarcted myocardium are functionally isolated from their host. Proceedings of the National Academy of Sciences, 100, 7808-7811. http://dx.doi.org/10.1073/pnas.1232447100

[13] Menasche, P. (2004) Skeletal myoblast transplantation for cardiac repair. Expert Review of Cardiovascular Therapy-Expert Reviews, 2, 21-28. http://dx.doi.org/10.1586/14779072.2.1.21

[14] Dib, N., Michler, R.E., Pagani, F.D., Wright, S., Kereiakes, D.J., Lengerich, R., Binkley, P., Buchele, D., Anand, I., Swingen, C., Di Carli, M.F., Thomas, J.D., Jaber, W.A., Opie, S.R., Campbell, A., McCarthy, P., Yeager, M., Dilsizian, V., Griffith, B.P., Korn, R., Kreuger, S.K., Ghazoul, M., MacLellan, W.R., Fonarow, G., Eisen, H.J., Dinsmore, J. and Diethrich, E. (2005) Safety and feasibility of autologous myoblast transplantation in patients with ischemic cardiomyopathy: Four-year follow-up. Circulation, 112, 1748-1755. http://dx.doi.org/10.1161/CIRCULATIONAHA.105.5478 $\underline{10}$

[15] Menasche, P., Hagege, A.A., Vilquin, J.T., Desnos, M., Abergel, E., Pouzet, B., Bel, A., Sarateanu, S., Scorsin, M., Schwartz, K., Bruneval, P., Benbunan, M., Marolleau, J.P. and Duboc, D. (2003) Autologous skeletal myoblast transplantation for severe postinfarction left ventricular dysfunction. Journal of the American College of Cardiology, 41, 1078-1083. http://dx.doi.org/10.1016/S0735-1097(03)00092-5

[16] Herreros, J., Prosper, F., Perez, A., Gavira, J.J., GarciaVelloso, M.J., Barba, J., Sanchez, P.L., Canizo, C., Rabago, G., Marti-Climent, J.M., Hernandez, M., LopezHolgado, N., Gonzalez-Santos, J.M., Martin-Luengo, C. and Alegria, E. (2003) Autologous intramyocardial injection of cultured skeletal muscle-derived stem cells in patients with non-acute myocardial infarction. European Heart Journal, 24, 2012-2020. http://dx.doi.org/10.1016/j.ehj.2003.09.012

[17] Pagani, F.D., DerSimonian, H., Zawadzka, A., Wetzel, K., Edge, A.S., Jacoby, D.B., Dinsmore, J.H., Wright, S., Aretz, T.H., Eisen, H.J. and Aaronson, K.D. (2003) Autologous skeletal myoblasts transplanted to ischemia-damaged myocardium in humans. Histological analysis of cell survival and differentiation. Journal of the American College of Cardiology, 41, 879-888.

http://dx.doi.org/10.1016/S0735-1097(03)00081-0

[18] Siminiak, T., Kalawski, R., Fiszer, D., Jerzykowska, O., Rzezniczak, J., Rozwadowska, N. and Kurpisz, M. (2004) Autologous skeletal myoblast transplantation for the treatment of postinfarction myocardial injury: Phase I clinical study with 12 months of follow-up. American Heart Journal, 148, 531-537. http://dx.doi.org/10.1016/j.ahj.2004.03.043

[19] Smits, P.C., van Geuns, R.J., Poldermans, D., Bountioukos, M., Onderwater, E.E., Lee, C.H., Maat, A.P. and Serruys, P.W. (2003) Catheter-based intramyocardial injection of autologous skeletal myoblasts as a primary treatment of ischemic heart failure: Clinical experience with six-month follow-up. Journal of the American Col- 
lege of Cardiology, 42, 2063-2069. http://dx.doi.org/10.1016/j.jacc.2003.06.017

[20] Hagege, A.A., Carrion, C., Menasche, P., Vilquin, J.T., Duboc, D., Marolleau, J.P., Desnos, M. and Bruneval, P. (2003) Viability and differentiation of autologous skeletal myoblast grafts in ischaemic cardiomyopathy. Lancet, 361, 491-492. http://dx.doi.org/10.1016/S0140-6736(03)12458-0

[21] Menasche, P., Alfieri, O., Janssens, S., McKenna, W., Reichenspurner, H., Trinquart, L., Vilquin, J.T., Marolleau, J.P., Seymour, B., Larghero, J., Lake, S., Chatellier, G., Solomon, S., Desnos, M. and Hagege, A.A. (2008) The Myoblast Autologous Grafting in Ischemic Cardiomyopathy (MAGIC) trial: first randomized placebo-controlled study of myoblast transplantation. Circulation, 117, 1189-1200.

http://dx.doi.org/10.1161/CIRCULATIONAHA.107.7341 $\underline{03}$

[22] Ferrari, G., Cusella-De Angelis, G., Coletta, M., Paolucci, E., Stornaiuolo, A., Cossu, G. and Mavilio, F. (1998) Muscle regeneration by bone marrow-derived myogenic progenitors. Science, 279, 1528-1530. http://dx.doi.org/10.1126/science.279.5356.1528

[23] Orlic, D., Kajstura, J., Chimenti, S., Jakoniuk, I., Anderson, S.M., Li, B., Pickel, J., McKay, R., Nadal-Ginard, B., Bodine, D.M., Leri, A. and Anversa, P. (2001) Bone marrow cells regenerate infarcted myocardium. Nature, 410, 701-705. http://dx.doi.org/10.1038/35070587

[24] Orlic, D., Kajstura, J., Chimenti, S., Limana, F., Jakoniuk, I., Quaini, F., Nadal-Ginard, B., Bodine, D.M., Leri, A. and Anversa, P. (2001) Mobilized bone marrow cells repair the infarcted heart, improving function and survival. Proceedings of the National Academy of Sciences, 98, 10344-10349. http://dx.doi.org/10.1073/pnas.181177898

[25] Jackson, K.A., Majka, S.M., Wang, H., Pocius, J., Hartley, C.J., Majesky, M.W., Entman, M.L., Michael, L.H., Hirschi, K.K. and Goodell, M.A. (2001) Regeneration of ischemic cardiac muscle and vascular endothelium by adult stem cells. Journal of Clinical Investigation, 107, 1395-1402. http://dx.doi.org/10.1172/JCI12150

[26] Balsam, L.B., Wagers, A.J., Christensen, J.L., Kofidis, T., Weissman, I.L. and Robbins, R.C. (2004) Haematopoietic stem cells adopt mature haematopoietic fates in ischaemic myocardium. Nature, 428, 668-673. http://dx.doi.org/10.1038/nature02460

[27] Vassilopoulos, G., Wang, P.R. and Russell, D.W. (2003) Transplanted bone marrow regenerates liver by cell fusion. Nature, 422, 901-904. http://dx.doi.org/10.1038/nature01539

[28] Alvarez-Dolado, M., Pardal, R., Garcia-Verdugo, J.M., Fike, J.R., Lee, H.O., Pfeffer, K., Lois, C., Morrison, S.J. and Alvarez-Buylla, A. (2003) Fusion of bone-marrowderived cells with Purkinje neurons, cardiomyocytes and hepatocytes. Nature, 425, 968-973. http://dx.doi.org/10.1038/nature02069

[29] Terada, N., Hamazaki, T., Oka, M., Hoki, M., Mastalerz, D.M., Nakano, Y., Meyer, E.M., Morel, L., Petersen, B.E. and Scott, E.W. (2002) Bone marrow cells adopt the phenotype of other cells by spontaneous cell fusion. $\mathrm{Na}$ - ture, 416, 542-545. http://dx.doi.org/10.1038/nature730

[30] Nygren, J.M., Jovinge, S., Breitbach, M., Sawen, P., Roll, W., Hescheler, J., Taneera, J., Fleischmann, B.K. and Jacobsen, S.E. (2004) Bone marrow-derived hematopoietic cells generate cardiomyocytes at a low frequency through cell fusion, but not transdifferentiation. Nature Medicine, 10, 494-501. http://dx.doi.org/10.1038/nm1040

[31] Laflamme, M.A. and Murry, C.E. (2005) Regenerating the heart. Nature Biotechnology, 23, 845-856. http://dx.doi.org/10.1038/nbt1117

[32] Kajstura, J., Rota, M., Whang, B., Cascapera, S., Hosoda, T., Bearzi, C., Nurzynska, D., Kasahara, H., Zias, E., Bonafe, M., Nadal-Ginard, B., Torella, D., Nascimbene, A., Quaini, F., Urbanek, K., Leri, A. and Anversa, P. (2005) Bone marrow cells differentiate in cardiac cell lineages after infarction independently of cell fusion. Circulation Research, 96, 127-137. http://dx.doi.org/10.1161/01.RES.0000151843.79801.60

[33] Yoon, Y.S., Wecker, A., Heyd, L., Park, J.S., Tkebuchava, T., Kusano, K., Hanley, A., Scadova, H., Qin, G., Cha, D.H., Johnson, K.L., Aikawa, R., Asahara, T. and Losordo, D.W. (2005) Clonally expanded novel multipotent stem cells from human bone marrow regenerate myocardium after myocardial infarction. Journal of Clinical Investigation, 115, 326-338.

[34] Caplan, A.I. and Dennis, J.E. (2006) Mesenchymal stem cells as trophic mediators. Journal of Cellular Biochemistry, 98, 1076-1084. http://dx.doi.org/10.1002/jcb.20886

[35] Bittira, B., Kuang, J.Q., Al-Khaldi, A., Shum-Tim, D. and Chiu, R.C. (2002) In vitro preprogramming of marrow stromal cells for myocardial regeneration. Annals of Thoracic Surgery, 74, 1154-1159, discussion 1159-1160. http://dx.doi.org/10.1016/S0003-4975(02)03857-2

[36] Makino, S., Fukuda, K., Miyoshi, S., Konishi, F., Kodama, H., Pan, J., Sano, M., Takahashi, T., Hori, S., Abe, H., Hata, J., Umezawa, A. and Ogawa, S. (1999) Cardiomyocytes can be generated from marrow stromal cells in vitro. Journal of Clinical Investigation, 103, 697-705. http://dx.doi.org/10.1172/JCI5298

[37] Miyahara, Y., Nagaya, N., Kataoka, M., Yanagawa, B., Tanaka, K., Hao, H., Ishino, K., Ishida, H., Shimizu, T., Kangawa, K., Sano, S., Okano, T., Kitamura, S. and Mori, H. (2006) Monolayered mesenchymal stem cells repair scarred myocardium after myocardial infarction. Nature Medicine, 12, 459-465. http://dx.doi.org/10.1038/nm1391

[38] Amado, L.C., Saliaris, A.P., Schuleri, K.H., St John, M., Xie, J.S., Cattaneo, S., Durand, D.J., Fitton, T., Kuang, J.Q., Stewart, G., Lehrke, S., Baumgartner, W.W., Martin, B.J., Heldman, A.W. and Hare, J.M. (2005) Cardiac repair with intramyocardial injection of allogeneic mesenchymal stem cells after myocardial infarction. Proceedings of the National Academy of Sciences of the United States of America, 102, 11474-11479. http://dx.doi.org/10.1073/pnas.0504388102

[39] Pittenger, M.F. and Martin, B.J. (2004) Mesenchymal stem cells and their potential as cardiac therapeutics. Circulation Research, 95, 9-20. http://dx.doi.org/10.1161/01.RES.0000135902.99383.6f

[40] Wollert, K.C., Meyer, G.P., Lotz, J., Ringes-Lichtenberg, 
S., Lippolt, P., Breidenbach, C., Fichtner, S., Korte, T., Hornig, B., Messinger, D., Arseniev, L., Hertenstein, B., Ganser, A. and Drexler, H. (2004) Intracoronary autologous bone-marrow cell transfer after myocardial infarction: The BOOST randomised controlled clinical trial. Lancet, 364, 141-148. http://dx.doi.org/10.1016/S0140-6736(04)16626-9

[41] Meyer, G.P., Wollert, K.C., Lotz, J., Steffens, J., Lippolt, P., Fichtner, S., Hecker, H., Schaefer, A., Arseniev, L., Hertenstein, B., Ganser, A. and Drexler, H. (2006) Intracoronary bone marrow cell transfer after myocardial infarction: Eighteen months' follow-up data from the randomized, controlled BOOST (BOne marrOw transfer to enhance ST-elevation infarct regeneration) trial. Circulation, 113, 1287-1294. http://dx.doi.org/10.1161/CIRCULATIONAHA.105.5751 $\underline{18}$

[42] Yousef, M., Schannwell, C.M., Kostering, M., Zeus, T., Brehm, M. and Strauer, B.E. (2009) The BALANCE Study: Clinical benefit and long-term outcome after intracoronary autologous bone marrow cell transplantation in patients with acute myocardial infarction. Journal of the American College of Cardiology, 53, 2262-2269. http://dx.doi.org/10.1016/j.jacc.2009.02.051

[43] Janssens, S., Dubois, C., Bogaert, J., Theunissen, K., Deroose, C., Desmet, W., Kalantzi, M., Herbots, L., Sinnaeve, P., Dens, J., Maertens, J., Rademakers, F., Dymarkowski, S., Gheysens, O., Van Cleemput, J., Bormans, G., Nuyts, J., Belmans, A., Mortelmans, L., Boogaerts, M. and Van de Werf, F. (2006) Autologous bone marrowderived stem-cell transfer in patients with ST-segment elevation myocardial infarction: Double-blind, randomised controlled trial. Lancet, 367, 113-121. http://dx.doi.org/10.1016/S0140-6736(05)67861-0

[44] Schachinger, V., Erbs, S., Elsasser, A., Haberbosch, W., Hambrecht, R., Holschermann, H., Yu, J., Corti, R., Mathey, D.G., Hamm, C.W., Suselbeck, T., Assmus, B., Tonn, T., Dimmeler, S. and Zeiher, A.M. (2006) Intracoronary bone marrow-derived progenitor cells in acute myocardial infarction. New England Journal of Medicine, 355, 1210-1221. http://dx.doi.org/10.1056/NEJMoa060186

[45] Lunde, K., Solheim, S., Aakhus, S., Arnesen, H., Abdelnoor, M., Egeland, T., Endresen, K., Ilebekk, A., Mangschau, A., Fjeld, J.G., Smith, H.J., Taraldsrud, E., Grogaard, H.K., Bjornerheim, R., Brekke, M., Muller, C., Hopp, E., Ragnarsson, A., Brinchmann, J.E. and Forfang, K. (2006) Intracoronary injection of mononuclear bone marrow cells in acute myocardial infarction. New England Journal of Medicine, 355, 1199-1209. http://dx.doi.org/10.1056/NEJMoa055706

[46] Perin, E.C., Dohmann, H.F., Borojevic, R., Silva, S.A., Sousa, A.L., Mesquita, C.T., Rossi, M.I., Carvalho, A.C., Dutra, H.S., Dohmann, H.J., Silva, G.V., Belem, L., Vivacqua, R., Rangel, F.O., Esporcatte, R., Geng, Y.J., Vaughn, W.K., Assad, J.A., Mesquita, E.T. and Willerson, J.T. (2003) Transendocardial, autologous bone marrow cell transplantation for severe, chronic ischemic heart failure. Circulation, 107, 2294-2302.

http://dx.doi.org/10.1161/01.CIR.0000070596.30552.8B
[47] Perin, E.C., Dohmann, H.F., Borojevic, R., Silva, S.A., Sousa, A.L., Silva, G.V., Mesquita, C.T., Belem, L., Vaughn, W.K., Rangel, F.O., Assad, J.A., Carvalho, A.C., Branco, R.V., Rossi, M.I., Dohmann, H.J. and Willerson, J.T. (2004) Improved exercise capacity and ischemia 6 and 12 months after transendocardial injection of autologous bone marrow mononuclear cells for ischemic cardiomyopathy. Circulation, 110, II213-II218. http://dx.doi.org/10.1161/01.CIR.0000138398.77550.62

[48] Fuchs, S., Satler, L.F., Kornowski, R., Okubagzi, P., Weisz, G., Baffour, R., Waksman, R., Weissman, N.J., Cerqueira, M., Leon, M.B. and Epstein, S.E. (2003) Catheter-based autologous bone marrow myocardial injection in no-option patients with advanced coronary artery disease: A feasibility study. Journal of the American College of Cardiology, 41, 1721-1724. http://dx.doi.org/10.1016/S0735-1097(03)00328-0

[49] Assmus, B., Honold, J., Schachinger, V., Britten, M.B., Fischer-Rasokat, U., Lehmann, R., Teupe, C., Pistorius, K., Martin, H., Abolmaali, N.D., Tonn, T., Dimmeler, S. and Zeiher, A.M. (2006) Transcoronary transplantation of progenitor cells after myocardial infarction. New England Journal of Medicine, 355, 1222-1232.

http://dx.doi.org/10.1056/NEJMoa051779

[50] Schachinger, V., Assmus, B., Britten, M.B., Honold, J., Lehmann, R., Teupe, C., Abolmaali, N.D., Vogl, T.J., Hofmann, W.K., Martin, H., Dimmeler, S. and Zeiher, A.M. (2004) Transplantation of progenitor cells and regeneration enhancement in acute myocardial infarction: Final one-year results of the TOPCARE-AMI Trial. Journal of the American College of Cardiology, 44, 16901699. http://dx.doi.org/10.1016/j.jacc.2004.08.014

[51] Abdel-Latif, A., Bolli, R., Tleyjeh, I.M., Montori, V.M., Perin, E.C., Hornung, C.A., Zuba-Surma, E.K., Al-Mallah, M. and Dawn, B. (2007) Adult bone marrow-derived cells for cardiac repair: A systematic review and metaanalysis. JAMA Internal Medicine, 167, 989-997.

http://dx.doi.org/10.1001/archinte.167.10.989

[52] Reffelmann, T., Konemann, S. and Kloner, R.A. (2009) Promise of blood- and bone marrow-derived stem cell transplantation for functional cardiac repair: Putting it in perspective with existing therapy. Journal of the American College of Cardiology, 53, 305-308. http://dx.doi.org/10.1016/j.jacc.2008.10.018

[53] Quirici, N., Soligo, D., Caneva, L., Servida, F., Bossolasco, P. and Deliliers, G.L. (2001) Differentiation and expansion of endothelial cells from human bone marrow CD133(+) cells. British Journal of Haematology, 115, 186194. http://dx.doi.org/10.1046/j.1365-2141.2001.03077.x

[54] Stamm, C., Westphal, B., Kleine, H.D., Petzsch, M., Kittner, C., Klinge, H., Schumichen, C., Nienaber, C.A., Freund, M. and Steinhoff, G. (2003) Autologous bone-marrow stemcell transplantation for myocardial regeneration. Lancet, 361, 45-46. http://dx.doi.org/10.1016/S0140-6736(03)12110-1

[55] Stamm, C., Kleine, H.D., Choi, Y.H., Dunkelmann, S., Lauffs, J.A., Lorenzen, B., David, A., Liebold, A., Nienaber, C., Zurakowski, D., Freund, M. and Steinhoff, G. (2007) Intramyocardial delivery of CD133+ bone marrow cells and coronary artery bypass grafting for chronic 
ischemic heart disease: Safety and efficacy studies. Journal of Thoracic and Cardiovascular Surgery, 133, 717-725. http://dx.doi.org/10.1016/i.jtcvs.2006.08.077

[56] Bartunek, J., Vanderheyden, M., Vandekerckhove, B., Mansour, S., De Bruyne, B., De Bondt, P., Van Haute, I., Lootens, N., Heyndrickx, G. and Wijns, W. (2005) Intracoronary injection of CD133-positive enriched bone marrow progenitor cells promotes cardiac recovery after recent myocardial infarction: Feasibility and safety. Circulation, 112, I178-I183.

[57] Losordo, D.W., Schatz, R.A., White, C.J., Udelson, J.E., Veereshwarayya, V., Durgin, M., Poh, K.K., Weinstein, R., Kearney, M., Chaudhry, M., Burg, A., Eaton, L., Heyd, L., Thorne, T., Shturman, L., Hoffmeister, P., Story, K., Zak, V., Dowling, D., Traverse, J.H., Olson, R.E., Flanagan, J., Sodano, D., Murayama, T., Kawamoto, A., Kusano, K.F., Wollins, J., Welt, F., Shah, P., Soukas, P., Asahara, T. and Henry, T.D. (2007) Intramyocardial transplantation of autologous CD34+ stem cells for intractable angina: A phase I/IIa double-blind, randomized controlled trial. Circulation, 115, 3165-3172.

http://dx.doi.org/10.1161/CIRCULATIONAHA.106.6873 $\underline{76}$

[58] Chen, S., Liu, Z., Tian, N., Zhang, J., Yei, F., Duan, B., Zhu, Z., Lin, S. and Kwan, T.W. (2006) Intracoronary transplantation of autologous bone marrow mesenchymal stem cells for ischemic cardiomyopathy due to isolated chronic occluded left anterior descending artery. Journal of Invasive Cardiology, 18, 552-556.

[59] Asahara, T., Murohara, T., Sullivan, A., Silver, M., van der Zee, R., Li, T., Witzenbichler, B., Schatteman, G. and Isner, J.M. (1997) Isolation of putative progenitor endothelial cells for angiogenesis. Science, 275, 964-966. http://dx.doi.org/10.1126/science.275.5302.964

[60] Iwasaki, H., Kawamoto, A., Ishikawa, M., Oyamada, A., Nakamori, S., Nishimura, H., Sadamoto, K., Horii, M., Matsumoto, T., Murasawa, S., Shibata, T., Suehiro, S. and Asahara, T. (2006) Dose-dependent contribution of CD34positive cell transplantation to concurrent vasculogenesis and cardiomyogenesis for functional regenerative recovery after myocardial infarction. Circulation, 113, 13111325.

http://dx.doi.org/10.1161/CIRCULATIONAHA.105.5412 $\underline{68}$

[61] Tatsumi, T., Ashihara, E., Yasui, T., Matsunaga, S., Kido, A., Sasada, Y., Nishikawa, S., Hadase, M., Koide, M., Nakamura, R., Irie, H., Ito, K., Matsui, A., Matsui, H., Katamura, M., Kusuoka, S., Matoba, S., Okayama, S., Horii, M., Uemura, S., Shimazaki, C., Tsuji, H., Saito, Y. and Matsubara, H. (2007) Intracoronary transplantation of non-expanded peripheral blood-derived mononuclear cells promotes improvement of cardiac function in patients with acute myocardial infarction. Circulation Journal, 71, 11991207. http://dx.doi.org/10.1253/circj.71.1199

[62] Erbs, S., Linke, A., Adams, V., Lenk, K., Thiele, H., Diederich, K.W., Emmrich, F., Kluge, R., Kendziorra, K., Sabri, O., Schuler, G. and Hambrecht, R. (2005) Transplantation of blood-derived progenitor cells after recanalization of chronic coronary artery occlusion: First randomized and placebo-controlled study. Circulation Re- search, 97, 756-762.

http://dx.doi.org/10.1161/01.RES.0000185811.71306.8b

[63] Kang, H.J., Lee, H.Y., Na, S.H., Chang, S.A., Park, K.W., Kim, H.K., Kim, S.Y., Chang, H.J., Lee, W., Kang, W.J., Koo, B.K., Kim, Y.J., Lee, D.S., Sohn, D.W., Han, K.S., Oh, B.H., Park, Y.B. and Kim, H.S. (2006) Differential effect of intracoronary infusion of mobilized peripheral blood stem cells by granulocyte colony-stimulating factor on left ventricular function and remodeling in patients with acute myocardial infarction versus old myocardial infarction: The MAGIC Cell-3-DES randomized, controlled trial. Circulation, 114, I145-I151.

http://dx.doi.org/10.1161/CIRCULATIONAHA.105.0011 $\underline{07}$

[64] Katritsis, D.G., Sotiropoulou, P.A., Karvouni, E., Karabinos, I., Korovesis, S., Perez, S.A., Voridis, E.M. and Papamichail, M. (2005) Transcoronary transplantation of autologous mesenchymal stem cells and endothelial progenitors into infarcted human myocardium. Catheterization and Cardiovascular Interventions, 65, 321-329. http://dx.doi.org/10.1002/ccd.20406

[65] Miyagawa, S., Matsumiya, G., Funatsu, T., Yoshitatsu, M., Sekiya, N., Fukui, S., Hoashi, T., Hori, M., Yoshikawa, H., Kanakura, Y., Ishikawa, J., Aozasa, K., Kawaguchi, N., Matsuura, N., Myoui, A., Matsuyama, A., Ezoe, S., Iida, H., Matsuda, H. and Sawa, Y. (2009) Combined autologous cellular cardiomyoplasty using skeletal myoblasts and bone marrow cells for human ischemic cardiomyopathy with left ventricular assist system implantation: Report of a case. Surgery Today, 39, 133-136. http://dx.doi.org/10.1007/s00595-008-3803-X

[66] Memon, I.A., Sawa, Y., Miyagawa, S., Taketani, S. and Matsuda, H. (2005) Combined autologous cellular cardiomyoplasty with skeletal myoblasts and bone marrow cells in canine hearts for ischemic cardiomyopathy. Journal of Thoracic and Cardiovascular Surgery, 130, 646653. http://dx.doi.org/10.1016/j.jtcvs.2005.02.024

[67] Takahashi, M., Li, T.S., Suzuki, R., Kobayashi, T., Ito, H., Ikeda, Y., Matsuzaki, M. and Hamano, K. (2006) Cytokines produced by bone marrow cells can contribute to functional improvement of the infarcted heart by protecting cardiomyocytes from ischemic injury. American Journal of Physiology-Heart and Circulatory Physiology, 291, H886-H893. http://dx.doi.org/10.1152/ajpheart.00142.2006

[68] Uemura, R., Xu, M., Ahmad, N. and Ashraf, M. (2006) Bone marrow stem cells prevent left ventricular remodeling of ischemic heart through paracrine signaling. Circulation Research, 98, 1414-1421. http://dx.doi.org/10.1161/01.RES.0000225952.61196.39

[69] Kamihata, H., Matsubara, H., Nishiue, T., Fujiyama, S., Tsutsumi, Y., Ozono, R., Masaki, H., Mori, Y., Iba, O., Tateishi, E., Kosaki, A., Shintani, S., Murohara, T., Imaizumi, T. and Iwasaka, T. (2001) Implantation of bone marrow mononuclear cells into ischemic myocardium enhances collateral perfusion and regional function via side supply of angioblasts, angiogenic ligands, and cytokines. Circulation, 104, 1046-1052. http://dx.doi.org/10.1161/hc3501.093817

[70] Kinnaird, T., Stabile, E., Burnett, M.S., Shou, M., Lee, 
C.W., Barr, S., Fuchs, S. and Epstein, S.E. (2004) Local delivery of marrow-derived stromal cells augments collateral perfusion through paracrine mechanisms. Circulation, 109, 1543-1549.

http://dx.doi.org/10.1161/01.CIR.0000124062.31102.57

[71] Kinnaird, T., Stabile, E., Burnett, M.S., Lee, C.W., Barr, S., Fuchs, S. and Epstein, S.E. (2004) Marrow-derived stromal cells express genes encoding a broad spectrum of arteriogenic cytokines and promote in vitro and in vivo arteriogenesis through paracrine mechanisms. Circulation Research, 94, 678-685. http://dx.doi.org/10.1161/01.RES.0000118601.37875.AC

[72] Askari, A.T., Unzek, S., Popovic, Z.B., Goldman, C.K., Forudi, F., Kiedrowski, M., Rovner, A., Ellis, S.G., Thomas, J.D., DiCorleto, P.E., Topol, E.J. and Penn, M.S. (2003) Effect of stromal-cell-derived factor 1 on stemcell homing and tissue regeneration in ischaemic cardiomyopathy. Lancet, 362, 697-703.

http://dx.doi.org/10.1016/S0140-6736(03)14232-8

[73] Takahashi, T., Kalka, C., Masuda, H., Chen, D., Silver, M., Kearney, M., Magner, M., Isner, J.M. and Asahara, T. (1999) Ischemia- and cytokine-induced mobilization of bone marrow-derived endothelial progenitor cells for neovascularization. Nature Medicine, 5, 434-438. http://dx.doi.org/10.1038/8462

[74] Misao, Y., Takemura, G., Arai, M., Ohno, T., Onogi, H., Takahashi, T., Minatoguchi, S., Fujiwara, T. and Fujiwara, H. (2006) Importance of recruitment of bone marrow-derived CXCR4+ cells in post-infarct cardiac repair mediated by G-CSF. Cardiovascular Research, 71, 455465. http://dx.doi.org/10.1016/j.cardiores.2006.05.002

[75] Klyushnenkova, E., Mosca, J.D., Zernetkina, V., Majumdar, M.K., Beggs, K.J., Simonetti, D.W., Deans, R.J. and McIntosh, K.R. (2005) T cell responses to allogeneic human mesenchymal stem cells: Immunogenicity, tolerance, and suppression. Journal of Biomedical Science, 12, 47-57. http://dx.doi.org/10.1007/s11373-004-8183-7

[76] Imanishi, Y., Saito, A., Komoda, H., Kitagawa-Sakakida, S., Miyagawa, S., Kondoh, H., Ichikawa, H. and Sawa, Y. (2008) Allogenic mesenchymal stem cell transplantation has a therapeutic effect in acute myocardial infarction in rats. Journal of Molecular and Cellular Cardiology, 44, 662-671. http://dx.doi.org/10.1016/j.yjmcc.2007.11.001

[77] Oh, H., Bradfute, S.B., Gallardo, T.D., Nakamura, T., Gaussin, V., Mishina, Y., Pocius, J., Michael, L.H., Behringer, R.R., Garry, D.J., Entman, M.L. and Schneider, M.D. (2003) Cardiac progenitor cells from adult myocardium: Homing, differentiation, and fusion after infarction. Proceedings of the National Academy of Sciences of the United States of America, 100, 12313-12318. http://dx.doi.org/10.1073/pnas.2132126100

[78] Chiavegato, A., Bollini, S., Pozzobon, M., Callegari, A., Gasparotto, L., Taiani, J., Piccoli, M., Lenzini, E., Gerosa, G., Vendramin, I., Cozzi, E., Angelini, A., Iop, L., Zanon, G.F., Atala, A., De Coppi, P. and Sartore, S. (2007) Human amniotic fluid-derived stem cells are rejected after transplantation in the myocardium of normal, ischemic, immuno-suppressed or immuno-deficient rat. Journal of Molecular and Cellular Cardiology, 42, 746-759. http://dx.doi.org/10.1016/j.yjmcc.2006.12.008
[79] Nakagami, H., Morishita, R., Maeda, K., Kikuchi, Y., Ogihara, T. and Kaneda, Y. (2006) Adipose tissue-derived stromal cells as a novel option for regenerative cell therapy. Journal of Atherosclerosis and Thrombosis, 13, 7781. http://dx.doi.org/10.5551/jat.13.77

[80] Messina, E., De Angelis, L., Frati, G., Morrone, S., Chimenti, S., Fiordaliso, F., Salio, M., Battaglia, M., Latronico, M.V., Coletta, M., Vivarelli, E., Frati, L., Cossu, G. and Giacomello, A. (2004) Isolation and expansion of adult cardiac stem cells from human and murine heart. Circulation Research, 95, 911-921. http://dx.doi.org/10.1161/01.RES.0000147315.71699.51

[81] Toma, C., Pittenger, M.F., Cahill, K.S., Byrne, B.J. and Kessler, P.D. (2002) Human mesenchymal stem cells differentiate to a cardiomyocyte phenotype in the adult murine heart. Circulation, 105, 93-98. http://dx.doi.org/10.1161/hc0102.101442

[82] Evans, M.J. and Kaufman, M.H. (1981) Establishment in culture of pluripotential cells from mouse embryos. $\mathrm{Na}$ ture, 292, 154-156. http://dx.doi.org/10.1038/292154a0

[83] Bel, A., Planat-Bernard, V., Saito, A., Bonnevie, L., Bellamy, V., Sabbah, L., Bellabas, L., Brinon, B., Vanneaux, V., Pradeau, P., Peyrard, S., Larghero, J., Pouly, J., Binder, P., Garcia, S., Shimizu, T., Sawa, Y., Okano, T., Bruneval, P., Desnos, M., Hagege, A.A., Casteilla, L., Puceat, M. and Menasche, P. (2010) Composite cell sheets: A further step toward safe and effective myocardial regeneration by cardiac progenitors derived from embryonic stem cells. Circulation, 122, S118-S123. http://dx.doi.org/10.1161/CIRCULATIONAHA.109.9272 $\underline{93}$

[84] Takahashi, K. and Yamanaka, S. (2006) Induction of pluripotent stem cells from mouse embryonic and adult fibroblast cultures by defined factors. Cell, 126, 663-676. http://dx.doi.org/10.1016/j.cell.2006.07.024

[85] Yu, J., Vodyanik, M.A., Smuga-Otto, K., AntosiewiczBourget, J., Frane, J.L., Tian, S., Nie, J., Jonsdottir, G.A., Ruotti, V., Stewart, R., Slukvin, I.I. and Thomson, J.A. (2007) Induced pluripotent stem cell lines derived from human somatic cells. Science, 318, 1917-1920. http://dx.doi.org/10.1126/science.1151526

[86] Takahashi, K., Tanabe, K., Ohnuki, M., Narita, M., Ichisaka, T., Tomoda, K. and Yamanaka, S. (2007) Induction of pluripotent stem cells from adult human fibroblasts by defined factors. Cell, 131, 861-872.

http://dx.doi.org/10.1016/j.cell.2007.11.019

[87] Hattori, F., Chen, H., Yamashita, H., Tohyama, S., Satoh, Y.S., Yuasa, S., Li, W., Yamakawa, H., Tanaka, T., Onitsuka, T., Shimoji, K., Ohno, Y., Egashira, T., Kaneda, R., Murata, M., Hidaka, K., Morisaki, T., Sasaki, E., Suzuki, T., Sano, M., Makino, S., Oikawa, S. and Fukuda, K. (2009) Nongenetic method for purifying stem cell-derived cardiomyocytes. Nature Methods, 7, 61-66. http://dx.doi.org/10.1038/nmeth.1403

[88] Seki, T., Yuasa, S., Oda, M., Egashira, T., Yae, K., Kusumoto, D., Nakata, H., Tohyama, S., Hashimoto, H., Kodaira, M., Okada, Y., Seimiya, H., Fusaki, N., Hasegawa, M. and Fukuda, K. (2010) Generation of induced pluripotent stem cells from human terminally differentiated circulating T cells. Cell Stem Cell, 7, 11-14. 
http://dx.doi.org/10.1016/j.stem.2010.06.003

[89] Miyagawa, S., Roth, M., Saito, A., Sawa, Y. and Kostin, S. (2011) Tissue-engineered cardiac constructs for cardiac repair. Annals of Thoracic Surgery, 91, 320-329. http://dx.doi.org/10.1016/j.athoracsur.2010.09.080

[90] Kawamura, M., Miyagawa, S., Miki, K., Saito, A., Fukushima, S., Higuchi, T., Kawamura, T., Kuratani, T., Daimon, T., Shimizu, T., Okano, T. and Sawa, Y. (2012) Feasibility, safety, and therapeutic efficacy of human induced pluripotent stem cell-derived cardiomyocyte sheets in a porcine ischemic cardiomyopathy model. Circulation, 126, S29-S37. http://dx.doi.org/10.1161/CIRCULATIONAHA.111.0843 $\underline{43}$

[91] Miki, K., Uenaka, H., Saito, A., Miyagawa S, Sakaguchi, T., Higuchi, T., Shimizu T, Okano, T., Yamanaka, S. and Sawa, Y. (2012) Bioengineered myocardium derived from induced pluripotent stem cells improves cardiac function and attenuates cardiac remodeling following chronic myocardial infarction in rats. Stem Cells Translational Medicine, 1, 430-437. http://dx.doi.org/10.5966/sctm.2011-0038

[92] Ieda, M., Fu, J.D., Delgado-Olguin, P., Vedantham, V., Hayashi, Y., Bruneau, B.G. and Srivastava, D. (2010) Direct reprogramming of fibroblasts into functional cardiomyocytes by defined factors. Cell, 142, 375-386. http://dx.doi.org/10.1016/j.cell.2010.07.002

[93] Miyagawa, S., Sawa, Y., Taketani, S., Kawaguchi, N., Nakamura, T., Matsuura, N. and Matsuda, H. (2002) Myocardial regeneration therapy for heart failure: Hepatocyte growth factor enhances the effect of cellular cardiomyoplasty. Circulation, 105, 2556-2561. http://dx.doi.org/10.1161/01.CIR.0000016722.37138.F2

[94] Gavira, J.J., Nasarre, E., Abizanda, G., Perez-Ilzarbe, M., de Martino-Rodriguez, A., Garcia de Jalon, J.A., Mazo, M., Macias, A., Garcia-Bolao, I., Pelacho, B., MartinezCaro, D. and Prosper, F. (2010) Repeated implantation of skeletal myoblast in a swine model of chronic myocardial infarction. European Heart Journal, 31, 1013-1021. http://dx.doi.org/10.1093/eurheartj/ehp342 